\title{
Crop Cycle Length Determines Optimal Transplanting Date for Seedlings from Hybrid True Potato Seeds
}

\author{
Luuk C. M. van Dijk ${ }^{1,2}$ D . Olivia C. Kacheyo ${ }^{2}$ (D) Michiel E. de Vries ${ }^{2}$ (D) $\cdot$ /III \\ Willemien J. M. Lommen ${ }^{1} \mathbb{D} \cdot$ Paul C. Struik $^{1}$ (D) \\ Received: 17 April 2021 / Accepted: 26 August 2021 / Published online: 14 December 2021
}

(c) The Author(s) 2021

\section{Abstract}

The technology of hybrid breeding in diploid potatoes creates opportunities to design novel and improved cultivation systems based on hybrid true potato seeds. A promising cultivation pathway to produce seed or ware tubers is by transplanting greenhouse-raised seedlings into the field. This study explored the effects of transplanting date and seedling age on tuber yield, using greenhouse-raised seedlings. Field trials with experimental hybrid genotypes were conducted in three consecutive years. In 2017 and 2018, 4- and 6-week-old seedlings were transplanted at four dates: March, April, May and June. In 2019, transplanting dates included April, May and June and seedling age was 5 weeks. In 2018, the March planting experienced severe frost during the initial field period resulting in crop failure. In 2017 and 2019, plants could withstand shorter and less severe frost events. Seedling age did not significantly affect tuber parameters. Transplanting in June resulted in lower marketable yield ( $>28 \mathrm{~mm}$ ) compared with earlier transplanting dates when crops were harvested in September. At full crop senescence, no differences in marketable yield were observed. The optimal transplanting window, taking into account weather-related risks, is approximately between early April and end May. For some genotypes, crop cycle length was observed to be a more important yield-determining factor than transplanting date.

Keywords Greenhouse nursery · Hybrid cultivation systems · Hybrid TPS · Potato cropping cycle $\cdot$ Seedling age $\cdot$ Solanum tuberosum $\mathrm{L}$. Transplanting date $\cdot$ True Potato Seed

Luuk C. M. van Dijk

luuk.vandijk@wur.nl

1 Centre for Crop Systems Analysis, Wageningen University and Research, Bornsesteeg 48, 6708 PE Wageningen, The Netherlands

2 Solynta, Dreijenlaan 2, 6703 HA Wageningen, The Netherlands 


\section{Introduction}

The novel technology of diploid hybrid breeding reported by Lindhout et al. (2011) has led to the introduction of hybrid true potato seeds (TPS) for potato production. To derive seed and ware tubers from hybrid TPS, various cultivation systems can be used. These include direct field sowing, field transplanting of greenhouse-raised seedlings and planting of seedling tubers derived from either transplanted or directly sown plants. All these systems can be used for further seed tuber multiplication or the production of ware tubers (Almekinders et al. 1996, 2009; van Dijk et al. 2021).

Greenhouse-raised seedlings for field production in potato have been widely used since the introduction of TPS. Transplanting is favoured over direct sowing as it shortens the duration of the field growing period compared with direct sowing in the field and advances growth at the start of the crop cycle (Wiersema 1984; Almekinders et al. 2009). Until now, potato crops derived from TPS-grown plant materials were not able to penetrate the existing potato value chains that are based on seed-tuber grown crops; hybrid TPS is expected to accelerate the transition from a conventional seed tuber-based system to a TPS-based system (Lindhout et al. 2011, 2018; Jansky et al 2016; Stokstad 2019). Presently, the first yield data of diploid hybrid TPS grown from greenhouse-raised seedlings have been reported as ranging between 25 and $30 \mathrm{Mg}$ /ha (van Dijk et al. 2021). Crops grown from seedling tubers derived from greenhouse-raised seedlings of diploid hybrid TPS yield between 16 and $52 \mathrm{Mg} / \mathrm{ha}$ (Stockem et al. 2020).

Transplanting of seedlings and other transplants, e.g. cuttings, is associated with the risk of poor seedling establishment in the field mostly influenced by transplant shock (cf. Snoek et al. 1985; Reekie et al. 2005, 2007). Potato seedlings are highly sensitive to transplant shocks and the field conditions under which transplanting is carried out (Almekinders et al. 1996; Muthoni et al. 2014; van Dijk et al. 2021). Moreover, transplants show a slower initial growth in the field than plants grown from seed tubers leading to a reduced interception of radiation (cf. Lommen 1999). A longer growth duration in the field might give transplants the opportunity to catch up with seed-tuber grown plants. Environmental factors such as temperature, daylength and global radiation are known to affect the length of the growth cycle by affecting the speed and duration of vegetative growth, tuber initiation and tuber bulking (Ewing and Struik 1992; Kooman et al. 1996a, b). One would expect a strong interaction between these environmental factors and genotype, resulting from specific responses of cultivars to accumulated environmental factors (combined environmental factors received in time) during the crop cycle, especially when planting seedlings on different dates.

Early transplanting and the use of larger-sized seedlings (cf. Everaarts et al. 1993; Kerbiriou et al. 2013) may provide possible solutions to advancing the crop growth cycle. Seedlings of larger size, due to advanced vegetative growth during the greenhouse nursery phase, lead to faster crop establishment in the field. Early transplanting, however, presents a risk of transplanting coinciding 
with unfavourable conditions such as frost (cf. Snoek et al 1985; Timmer et al. 1989; Neuvel et al. 1991), for which potato is sensitive (Hijmans et al. 2003; Bethke et al. 2019). Large, over-developed transplants (BBCH stage 109 and further, Kacheyo et al. 2021) are also associated with high risk of mechanical damage during transplanting, and with increased transpiration rates (Reekie et al. 2005, 2007) which can cause wilting of the seedling (Snoek et al. 1985). On the other hand, transplanting of small, under-developed seedlings (BBCH stage $<102$, Kacheyo et al. 2021) in open field conditions leads to delayed establishment and growth of seedlings, which negatively impacts the length of the crop growth cycle (Everaarts et al. 1993; Kerbiriou et al. 2013).

The typical Dutch planting season for arable crops, from mid-March to mid-May, is known for its fluctuating daily minimum and maximum temperatures; both frost during the day and temperatures above $25{ }^{\circ} \mathrm{C}$ are possible. This necessitates the need to investigate how well a potato crop grown from transplants will perform when transplanted before mid-May.

Understanding the accumulated effects of environmental factors during a cropping cycle is necessary for defining an optimal period for field transplanting. Similarly, exploring the effects of seedling age on crop development and ultimately tuber yield is essential for defining the ideal transplantable seedling. For hybrid TPS-derived seedlings, the accumulated environmental effects during the cropping cycle, the timing of transplanting during the field season, the environmental conditions at the time of transplanting and the age of the hybrid seedlings at the time of transplanting have not yet been studied, but this knowledge is needed for successful adoption of hybrid TPS by farmers. It is assumed that an early transplanting date might be beneficial to crop yield, but comes with the risks of frost. A late transplanting date might reduce crop yield due to a shorter field period compared with earlier dates.

The aim of this study was to establish - under Dutch agronomic conditions - the effects of (1) the timing of field transplanting and (2) the seedling age at the date of transplanting on tuber yield in different size classes and to understand (3) how accumulated environmental factors impact the effects of the transplanting date. Several field experiments were carried out across three seasons with multiple experimental hybrid genotypes. In the final experimental year, an additional harvest was added at complete crop senescence to observe the yield differences between a fully matured crop compared with a harvest at a conventional date in September.

This study was part of the Potarei project; this project explored scenarios for novel and improved cultivation pathways for potato based on diploid hybrid true potato seeds, using experimental hybrid genotypes to gain first insights. The project aimed to lay foundation for further research in potato cultivation pathways for hybrid potato. Therefore, this study will also elaborate on additional studies on specific aspects which are important to operationalise a practical cultivation system for transplanted hybrid potato seedlings. 


\section{Materials and Methods}

\section{Hybrid Potato Genotypes}

In the course of 3 years, seven experimental hybrids originating from the hybrid potato breeding company Solynta were used for experiments. Lindhout et al. (2018) gave a detailed description of the genetic background of the breeding program from which the used experimental hybrids originated. Due to the experimental nature of the genetic material, large commercial size seed quantities were not available. Therefore, it was decided to use the most advanced and most homogeneous material available in each year. In 2017, genotypes HOl and HO2 were used, in $2018 \mathrm{HO3}$ and $\mathrm{HO}$ and in $2019 \mathrm{HO3}, \mathrm{HO7}, \mathrm{HOS}$ and H09. Known characteristics related to the ontology of the experimental genotypes used are described in Supplementary Table S1. The numeric code of the genotypes signifies advancement in performance of the hybrids where $\mathrm{HOl}$ and $\mathrm{HO2}$ were clearly 'less-advanced' hybrids compared with the other hybrids in subsequent years.

\section{Production and Transplanting of Seedlings}

Seedlings were raised in a greenhouse compartment following the protocol described by van Dijk et al. (2021). Thereafter, they were transferred to a screenhouse for a 1-week hardening-off phase to reduce the transplant shock (cf. Snoek et al. 1985; Poll et al. 1994). On the dates of field planting in 2017 and 2018, seedlings of different age treatments had been raised for 4 or 6 weeks after sowing. In 2019, all seedlings past a 5-week-long nursery period.

One day prior to transplanting, uniform, transplantable seedlings were selected. Selection criteria were as follows: 4-week-old seedlings with a stem of 2-3 cm and 2-4 true leaves, 5-week-old seedlings with a stem of 7-12 $\mathrm{cm}$ and 5-8 leaves and 6 -week-old seedlings with a stem $>14 \mathrm{~cm}$ and $>8$ true leaves $(\mathrm{BBCH}$ stages 102-104, 105-108 and 109, respectively; Kacheyo et al. 2021).

\section{Field Locations and Experimental Design}

Field experiments were conducted at Nergena $\left(51^{\circ} 59^{\prime} 40^{\prime \prime} \mathrm{N}, 5^{\circ} 39^{\prime} 24^{\prime \prime} \mathrm{E}\right)$, the Netherlands, on a sandy soil, in three seasons $(2017,2018,2019)$.

In both 2017 and 2018, a field experiment was conducted to assess the effects of the transplanting date and the age of the seedlings at transplanting. The experiment was a split-plot experiment containing four replicated blocks. Four transplanting dates (March, April, May, June) were randomly assigned to the main plots (Table 1). Two seedling ages (4 weeks and 6 weeks at transplanting in both years) and two genotypes (HO1, HO2 in 2017 and HO3, HO4 in 2018) were assigned to the sub-plots (Table 1). Gross plots $(3.00 \times 1.80 \mathrm{~m})$ consisted of four rows, spaced at $0.75 \mathrm{~m}$, and nine seedlings per row, spaced at $0.20 \mathrm{~m}$, creating a planting density of 6.67 plants/ $\mathrm{m}^{2}$. Net plots included the middle two rows with five seedlings each $(1.50 \times 1.00 \mathrm{~m})$. 
Table 1 Experimental details

\begin{tabular}{|c|c|c|c|c|c|c|}
\hline \multirow[t]{3}{*}{ Year $^{\mathrm{a}}$} & \multirow{3}{*}{$\begin{array}{l}\text { Coding of planting } \\
\text { dates }\end{array}$} & \multirow[t]{3}{*}{ Genotype } & \multirow[t]{3}{*}{ Seedling age } & \multicolumn{3}{|l|}{ Dates of: } \\
\hline & & & & \multirow[t]{2}{*}{ Planting } & \multicolumn{2}{|l|}{ Harvest } \\
\hline & & & & & September & Senescence \\
\hline 2017 & $\begin{array}{l}\text { March, April, } \\
\text { May, June }\end{array}$ & H01, H02 & $\begin{array}{l}4 \text { weeks, } \\
6 \text { weeks }\end{array}$ & $\begin{array}{l}21 \text { March } \\
13 \text { April } \\
\text { 11 May } \\
7 \text { June }\end{array}$ & 21 September & \\
\hline 2018 & $\begin{array}{l}\text { March, April, } \\
\text { May, June }\end{array}$ & H03, H04 & $\begin{array}{l}4 \text { weeks, } \\
6 \text { weeks }\end{array}$ & $\begin{array}{l}\text { 14 March } \\
\text { 10 April } \\
9 \text { May } \\
6 \text { June }\end{array}$ & 20 September & \\
\hline 2019 & April, May, June & $\begin{array}{l}\text { H03, H07, } \\
\text { H08, H09 }\end{array}$ & 5 weeks & $\begin{array}{l}9 \text { April } \\
7 \text { May } \\
4 \text { June }\end{array}$ & $\begin{array}{l}\text { 4 September } \\
10 \text { September } \\
10 \text { September }\end{array}$ & $\begin{array}{l}10 \text { October } \\
10 \text { October } \\
9 \text { November }\end{array}$ \\
\hline
\end{tabular}

${ }^{\mathrm{a}}$ In 2017 and 2018, experiments were laid out in 4 blocks, in 2019 in 2 blocks

${ }^{\mathrm{b}}$ The March planting in 2018 got killed by frost during the first 2 weeks in the field

Seedlings were hand-transplanted in small ridges with the seedlings' peat moss plug covered with about $1 \mathrm{~cm}$ of soil (see van Dijk et al. 2021 for more details); see Table 1 and Figs. 1a-d, 2a-b. Harvest of all transplanting dates was conducted on 21 September in 2017 and on 20 September in 2018 (Table 1 and Figs. 1a-d, 2a-b), in line with the conventional harvest date in Dutch potato production. At the date of harvest, the crop was in principal growth stages 907, 905, 905 and 901 according to the BBCH scale for transplanting dates March to June, respectively (Kacheyo et al. 2021). In both years, all tubers (>20 mm) obtained from the net plots were used for the necessary measurements.

In 2019, a field experiment was conducted to assess the effects of transplanting date and harvest on tuber yield. The experiment had a split-plot with two replicated blocks. Three transplanting dates (April, May and June) were assigned to the main plots and four genotypes (H03, H07, HOS and H09) plus the two harvest dates, September harvest and - full - senescence harvest (Table 1), were assigned to the sub-plots. Plots $(3.00 \times 1.96 \mathrm{~m})$ consisted of four rows, spaced at $75 \mathrm{~cm}$, and seven seedlings per row, spaced at $28 \mathrm{~cm}$, creating a plant density of 4.76 plants $/ \mathrm{m}^{2}$. The September harvest took place when crop stages were comparable with those of the harvest dates in 2017 and 2018 (Table 1 and Figs. 1e-f, 2c). Hence, the tubers of the April and May transplanting dates were harvested on 4 and 10 September respectively when the haulm was $>50 \%$, but not yet completely senesced (BBCH stage 905-906, Kacheyo et al. 2021). The June transplanting date was harvested on 10 September, when the complete haulm had sagged and senescing had just started (BBCH stage 901, Kacheyo et al. 2021). For all transplanting dates in 2019, the senescence harvest took place when the whole haulm was fully senesced $(\mathrm{BBCH}$ stage 907, Kacheyo et al. 2021; Table 1 and Figs. 1e-f, 2c), which occurred on 10 October for transplanting dates April and May and on 9 November for transplanting date June. During all harvest dates in 2019 , tubers of whole plots $\left(5.88 \mathrm{~m}^{2}\right)$ consisting of 28 plants were lifted. Moreover, at the September harvest, all tubers $>10 \mathrm{~mm}$ 
were included in the measurements whereas at full senescence, all tubers $>20 \mathrm{~mm}$ were taken into account.

\section{Cultural Practices}

Immediately after transplanting, seedlings were irrigated and received at least $0.5 \mathrm{~L}$ water per $\mathrm{m}$ row (at least $0.1 \mathrm{~L} / \mathrm{seedling}$ ), as described in van Dijk et al. (2021). This promoted fast recovery from transplanting as water-limited conditions were avoided. Furthermore, irrigation to supplement precipitation when necessary was applied by a boom irrigation system, see Fig. 2. When daily minimum temperatures were forecasted to decrease to $<1-2{ }^{\circ} \mathrm{C}$, plants were covered with a transparent perforated plastic film, as used in conventional Dutch vegetable crop production (Snoek et al. 1985; Timmer et al. 1989; Neuvel et al. 1991; de Kraker et al. 1993); see Fig. 1b, $\mathrm{d}$, f. The film was removed when temperatures were forecasted to rise $>15^{\circ} \mathrm{C}$ for a period of $>3 \mathrm{~h}$.

Between transplanting and $100 \%$ ground cover, ridges were earthened-up in two operations to the size of a conventional potato ridge. Weeding was done by hand to avoid undesirable and unpredictable effects of herbicides on the experimental potato hybrids. Fertiliser and fungicide applications were carried out following Dutch potato cultivation recommendations.

\section{Observations, Measurements and Calculations}

Daily weather data were recorded at weather station the Veenkampen, located at $2.9 \mathrm{~km}$ West from the trial fields. Data included minimum and maximum temperatures (T-min \& T-max, Fig. 1b, d, f) and precipitation (Fig. 2). Daily incident photosynthetically active radiation (PAR) was calculated from the mean incoming solar radiation per day $\left(\mathrm{Q}_{\mathrm{Global}(\mathrm{IN})}\right)$

$$
P A R=\frac{0.45 \times Q_{\text {Global(IN) }} \times D}{10^{6}}
$$

where $P A R$ is in $\mathrm{MJ} / \mathrm{m}^{2} /$ day, $Q_{\text {Global(IN) }}$ was measured in $\mathrm{W} / \mathrm{m}^{2}$ and $D$ corresponds with the total number of seconds per day. The accumulation of received PAR per transplanting date per season is shown in Fig. 1a, c, e as PAR- $\Sigma$. Applied irrigation was measured in the field using two rain gauges. The total received water (irrigation + precipitation) per transplanting date per season is shown as received water- $\Sigma$ in Fig. 2. The total received temperature (with a base temperature (T-base) of $0{ }^{\circ} \mathrm{C}$ ) per transplanting date per season is shown as T- $\Sigma$ in Fig. $1 \mathrm{~b}, \mathrm{~d}, \mathrm{f}$.

In 2017's and at 2019's September harvest, tuber measurements were carried out by hand. First, samples were cleaned per plot to remove sand, other plant parts and small tubers, using thresholds of $20 \mathrm{~mm}$ in 2017 and $10 \mathrm{~mm}$ in 


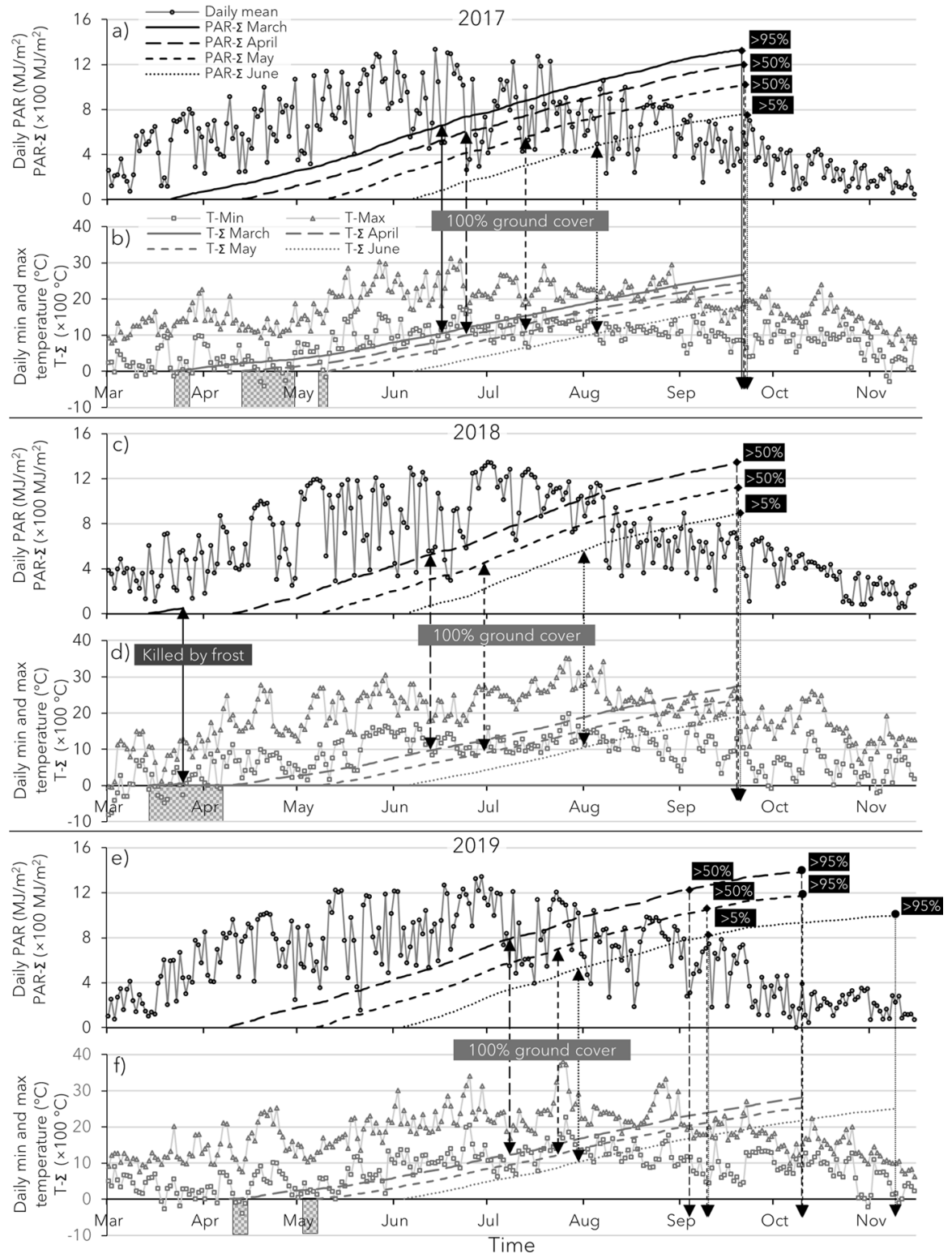

Fig. 1 Daily incident photosynthetic active radiation (PAR) from March to mid-November (field season) and PAR sum (PAR- $\Sigma$ ) per transplanting date are depicted in panels a, $\mathbf{c}$ and $\mathbf{e}$ for the respective years. Panels $\mathbf{b}, \mathbf{d}$ and $\mathbf{f}$ show the daily minimum (T-min) and maximum (T-max) temperature and the temperature sum $\left(\mathrm{T}-\Sigma, \mathrm{T}\right.$-base $\left.=0{ }^{\circ} \mathrm{C}\right)$ per transplanting date. Periods when plastic film was applied are highlighted with a grey blocked pattern. Across the panels, vertical arrows indicate the events of reaching $100 \%$ ground cover and harvest per transplanting date, which are additionally flagged with their estimated percentage of crop senescence 

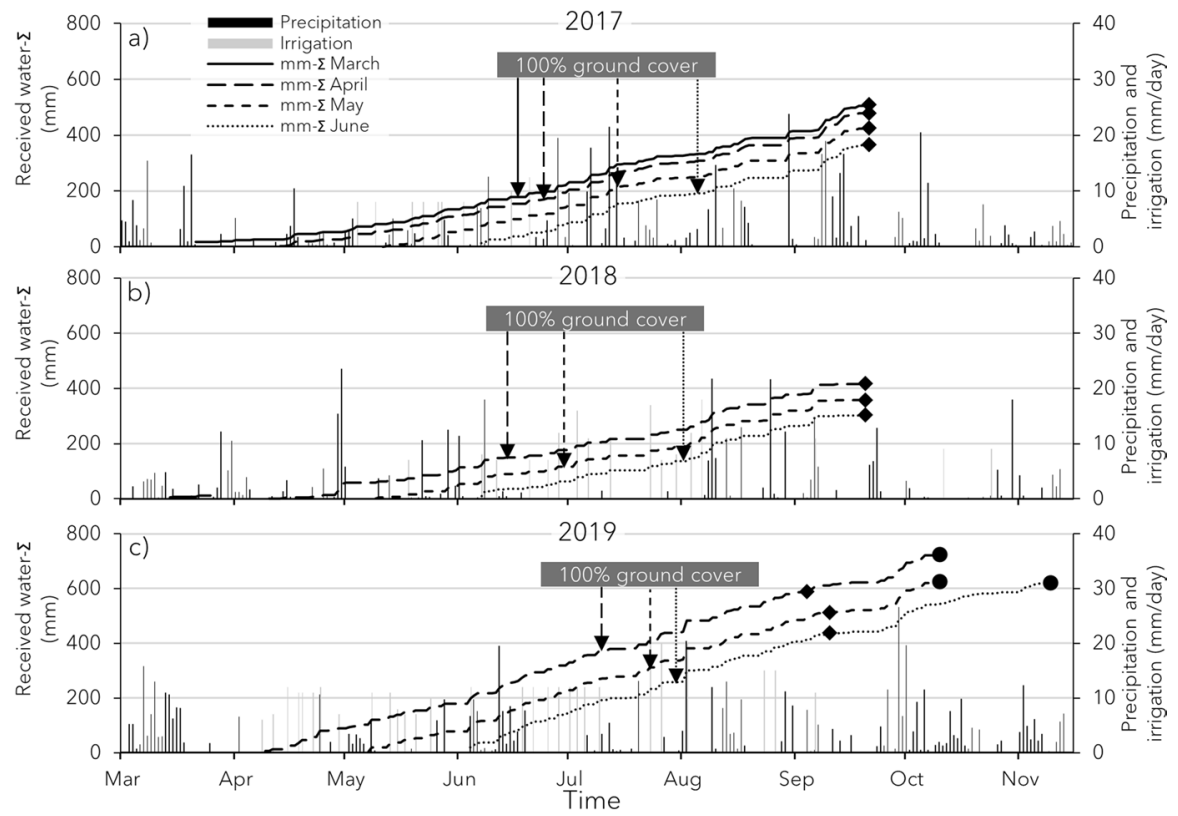

Fig. 2 Daily precipitation, applied irrigation and total received water sum (water- $\Sigma$ ) during the field period from March to mid-November for each of the transplanting dates. The date of $100 \%$ ground cover per transplanting date is indicated with vertical arrows corresponding with transplanting date curve pattern. For all years, the harvest dates in September are indicated with black diamonds. The harvests for the fully senesced crops in 2019 are indicated with black circles

September 2019. Secondly, total tuber fresh weight (FW) and number of tubers were assessed per plot. Individual tubers were graded into tuber size categories, using a square measure. Per tuber size class, tuber FW and number of tubers were assessed. In 2017, tubers were graded into the size classes (sc) $20<\mathrm{sc} \leq 28$, $28<\mathrm{sc} \leq 40,40<\mathrm{sc} \leq 50$ and sc $>50 \mathrm{~mm}$. During 2019's September harvest, tubers were graded into $10<\mathrm{sc} \leq 28,28<\mathrm{sc} \leq 40$ and $\mathrm{sc}>40 \mathrm{~mm}$. In 2018 and at 2019's senescence harvest, tubers were processed by an automated phenotyping line, as explained by Stockem et al. (2020) and detailed by van Dijk et al. (2021). The tuber phenotyping line included a 3D camera to assess tuber size and volume per individual tuber, which were used to calculate tuber FW and number of tubers per size class. The set size categories of the phenotyping line were equal to 2017's measurements, which were done by hand. Measured tuber FW and numbers of tubers per plot were converted into data per ha. For 2017, 2018 and 2019's senescence harvest, the tuber size thresholds of $>20$ (=total tubers), $>28$ (=marketable tubers), $>40,>50 \mathrm{~mm}$ and $28<\mathrm{sc} \leq 50 \mathrm{~mm}$ (=seed tubers) were used to obtain insights into tuber yield in different size classes. As the tuber grades at 2019's September harvest were slightly different, tuber size thresholds of $>10$ (=total tubers $),>28$ (=marketable tubers) and $>40 \mathrm{~mm}$ were used. 


\section{Statistical Analysis}

The programme GenStat 19th edition (VSN International Ltd. 2019) was used for statistical analyses. All experiments were analysed as spit-plot designs with a general analysis of variance. In 2017 and 2018, the significance of main effects and interactions of date, age and genotype were assessed. At the lowest level (sub-plot level), the age $\times$ genotype combinations were clustered and randomised within the date (main plot level), which was randomised in the block factor.

In 2019, the significance of main effects of date and genotype and their interactions were assessed for the September and senescence harvests separately. All significant factor or interaction means were compared using Fisher's protected LSD test $(\alpha=0.05)$.

\section{Results}

\section{Field Management and Weather Conditions During the Three Experimental Years}

In 2017, the seedlings were transplanted in ridges with a different ridge shape and height resulting in a different seedling position relative to the ridge top and ground level compared with later seasons, where initial ridges were smaller (van Dijk et al. 2021). In 2018 and 2019, a distinct V-shape in the ridge centre improved the ridges and allowed transplanting of seedlings deep in the ridge and close to the ridge base, thereby protecting seedlings against strong winds in a sheltered micro-environment (van Dijk et al. 2021). The V-shape was also able to support the plastic film, in contrast to the flatter ridge in 2017 where the seedlings supported the film resulting in damage to the seedlings.

Temperature In 2017, for transplanting dates March and April, minimum temperatures of $<2{ }^{\circ} \mathrm{C}$ were observed for at least 10 days during the first 4 weeks after transplanting (Fig. 1b). Seedlings were covered with a plastic film, which, however, pressed down the plant tops and the leaves. The contact of film and seedlings caused visible frost damage: brownish discolouration followed by senescence of the damaged leaves (cf. Snoek et al. 1985). Although damaged, seedlings managed to recover when daily maximum temperatures increased above c. $15{ }^{\circ} \mathrm{C}$.

In 2018, the first field-week after the March transplanting, on 14 March, included low day and night temperatures, dropping to a minimum of $-4.9{ }^{\circ} \mathrm{C}$ (Fig. 1d). Despite the improved ridges and covering with a plastic film, the seedlings were heavily affected by the frost period. Increased temperatures in the second week after transplanting and onwards (see Fig. 1c, d) did not allow seedling recovery and all plants had died by 25 March. Analysis of the results of 2018 therefore excluded the March planting date as no data were collected.

In 2019, no March planting was carried out anymore. In this year, the April date coincided with minimum temperatures $<2{ }^{\circ} \mathrm{C}$ on a daily base in the first week after transplanting (Fig. 1f). Even with improved ridges, covered by a plastic film, top leaves of seedlings were damaged by frost. From the second week onwards, 
minimum and maximum temperatures gradually increased (Fig. 1f) resulting in recovery of the seedlings of 2019's April date.

During the 2017, 2018 and 2019 field periods, recorded maximum temperatures were $31.3,35.2$ and $38.0^{\circ} \mathrm{C}$ (Fig. $1 \mathrm{~b}, \mathrm{~d}, \mathrm{f}$ ). The number of days with temperatures $>30^{\circ} \mathrm{C}$ was 3,10 and 11 days, respectively.

Water The received water- $\Sigma$ in Fig. 2 shows that among all seasons, from planting to September harvest, 2019 received the most water. In 2017, transplanting dates March, April, May and June received on average 2.8, 3.0, 3.2 and $3.4 \mathrm{~mm} /$ day, respectively. For 2018, March excluded, these values were 2.6, 2.7 and $2.9 \mathrm{~mm} /$ day. In 2019, the planting dates April, May and June received on average 3.9, 4.0 and $3.9 \mathrm{~mm} /$ day, respectively, which was for every transplanting date $0.5-1.3 \mathrm{~mm} /$ day more than in previous years.

Besides the September harvest, a full-senescence harvest was carried out in 2019. From October, in the final phase of the season, it was observed that the difference in crop development between planting dates April and May became smaller. Therefore, the date of full crop senescence (BBCH stage 907, Kacheyo et al. 2021) was around 10 October for both planting dates (Fig. 1e, f), which was 184 days after transplanting (DAT) for the April planting date and 156 DAT for the May date. The June transplanting date took one more month before complete senescence. It was observed that night frost late October (Fig. 1f) accelerated the process of crop senescence.

\section{Effects of Seedling Age on Yield and Number of Tubers}

No significant effects of age were found on total yield and number of tubers in 2017 and 2018 (Table 2), nor were there any significant interactions between seedling age and the transplanting date or genotype. In these years, 4- and 6-week-old seedlings were transplanted on each date. In 2019, only 5-week-old seedlings were used on each transplanting date because of the lack of seedling age effect observed in the previous years.

\section{Effects of Transplanting Date on Yield and Number of Tubers on a Conventional Harvest Date}

Following the conventional date of potato harvest in the Netherlands, all three experimental years included a September harvest, see Table 1. Significantly lower yields were generally observed in the June transplanting date as compared with the earlier transplanting dates in 2017 and 2019 (see also Fig. 3a-h). On the other hand, no significant differences in yield were observed between the March and May transplanting dates in 2017 and April to May dates in 2018 and 2019 (Tables 2 and 3).

Marketable Tubers (>28 mm) In 2017, significant effects of transplanting date were observed on both yield and number of marketable tubers per ha (Table 2). The 


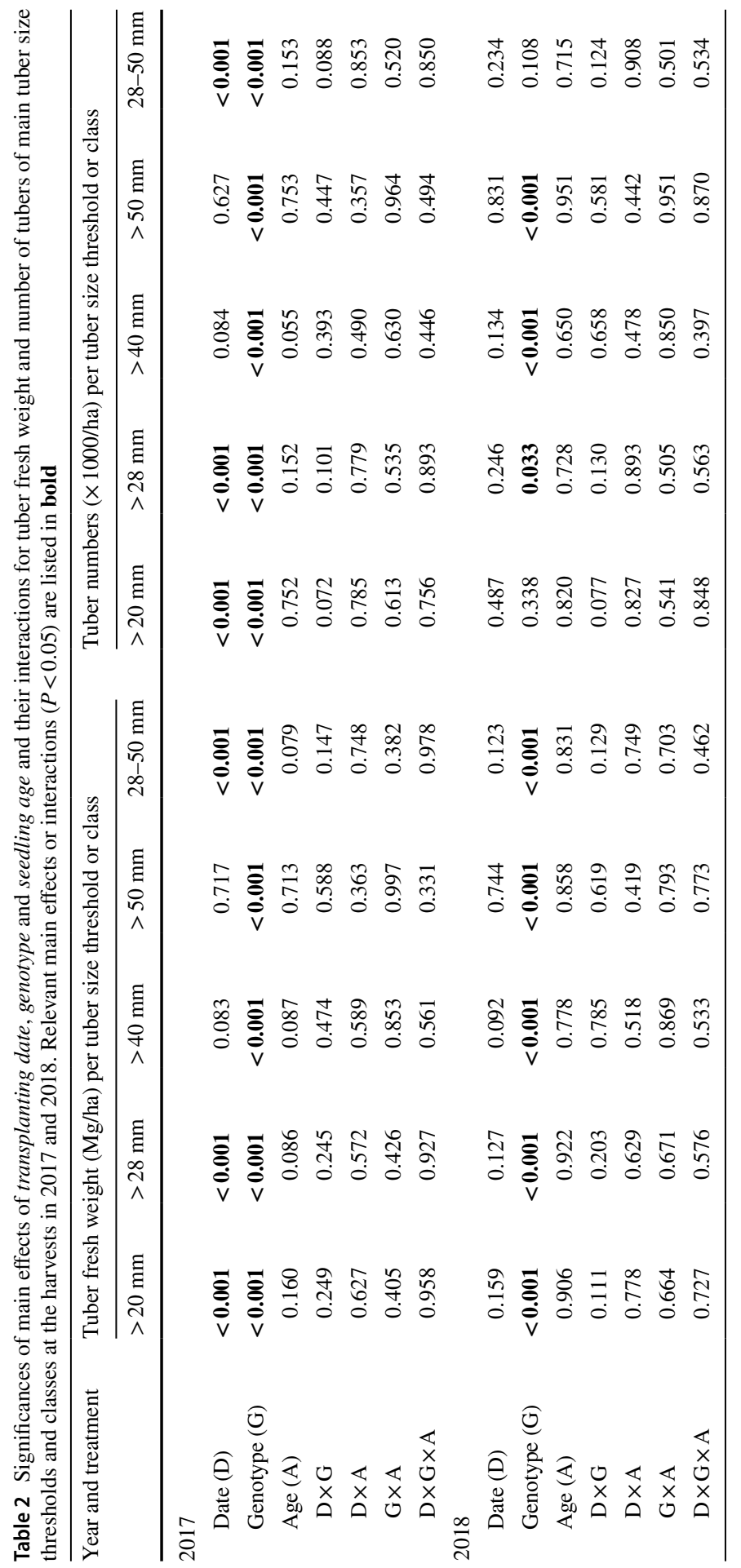



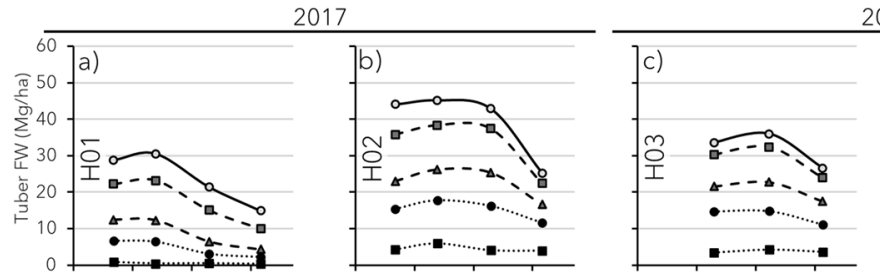

2018

2019 Septemberharvest
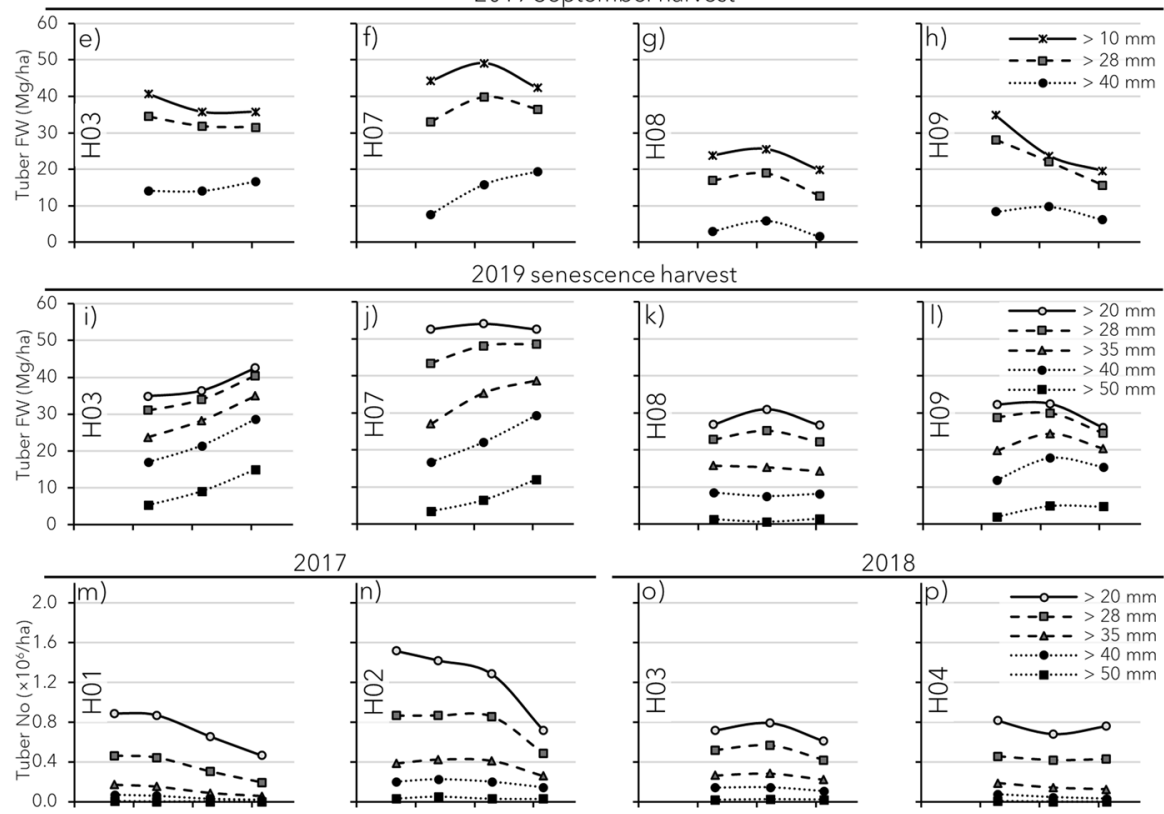

2017
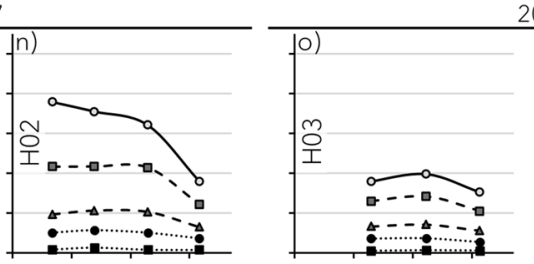

2018
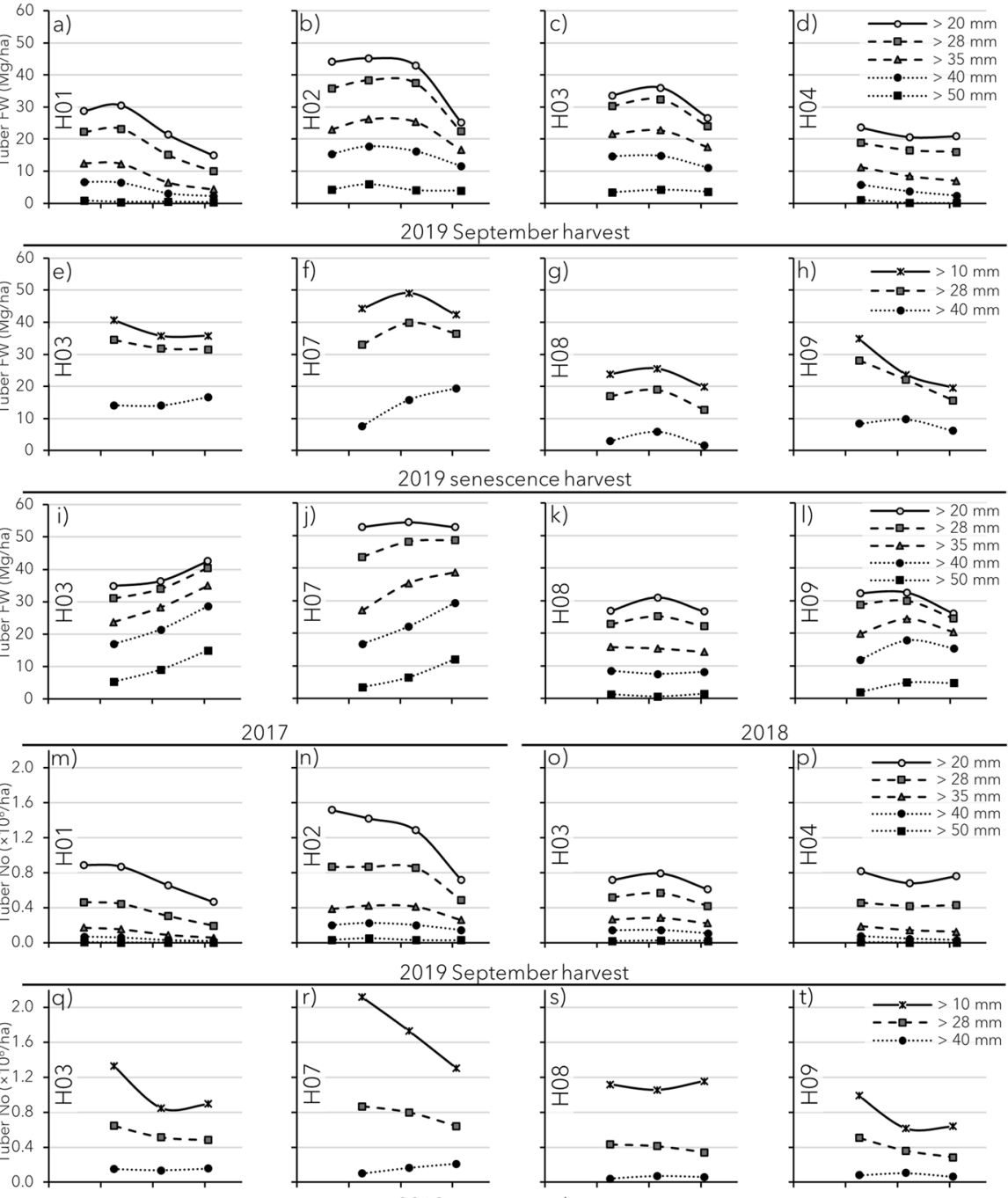

2019 senescence harvest
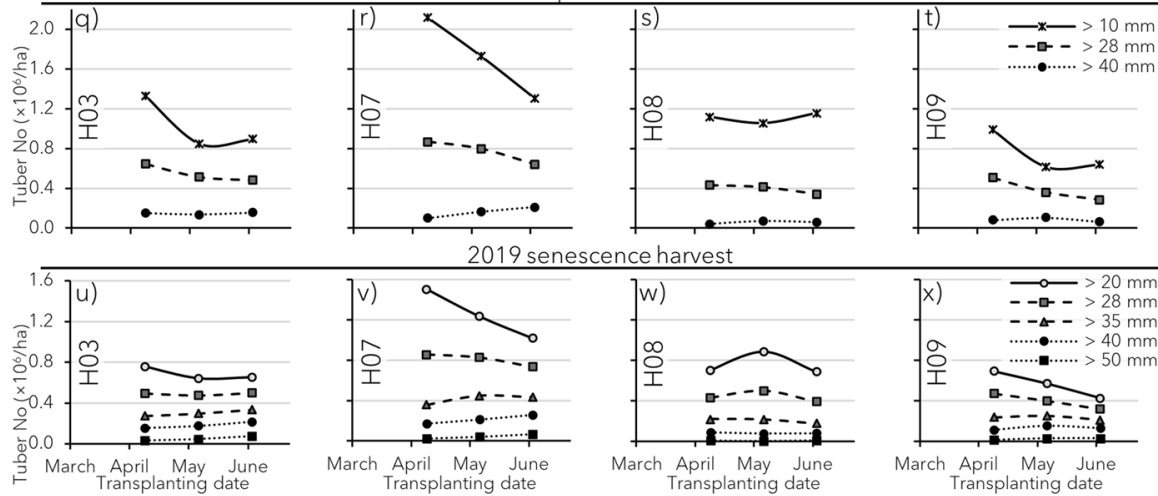

Fig. 3 Tuber yield (panels a-l) and number of tubers (panels $\mathbf{m}-\mathbf{x}$ ) per ha split by genotype in 2017, 2018 and 2019 September and senescence harvest. 2017 H01 (a and m), 2017 H02 (b and n), 2018 H03 (c and o), 2018 H04 (d and p), 2019 September harvest H03 (e and q), 2019 September harvest H07 (f and r), 2019 September harvest H08 (g and s), 2019 September harvest H09 (h and t), 2019 Senescence harvest H03 (i and u), 2019 senescence harvest H07 (j and v), 2019 senescence harvest H08 (k and w), 2019 senescence harvest H09 (l and $\mathbf{x})$ 


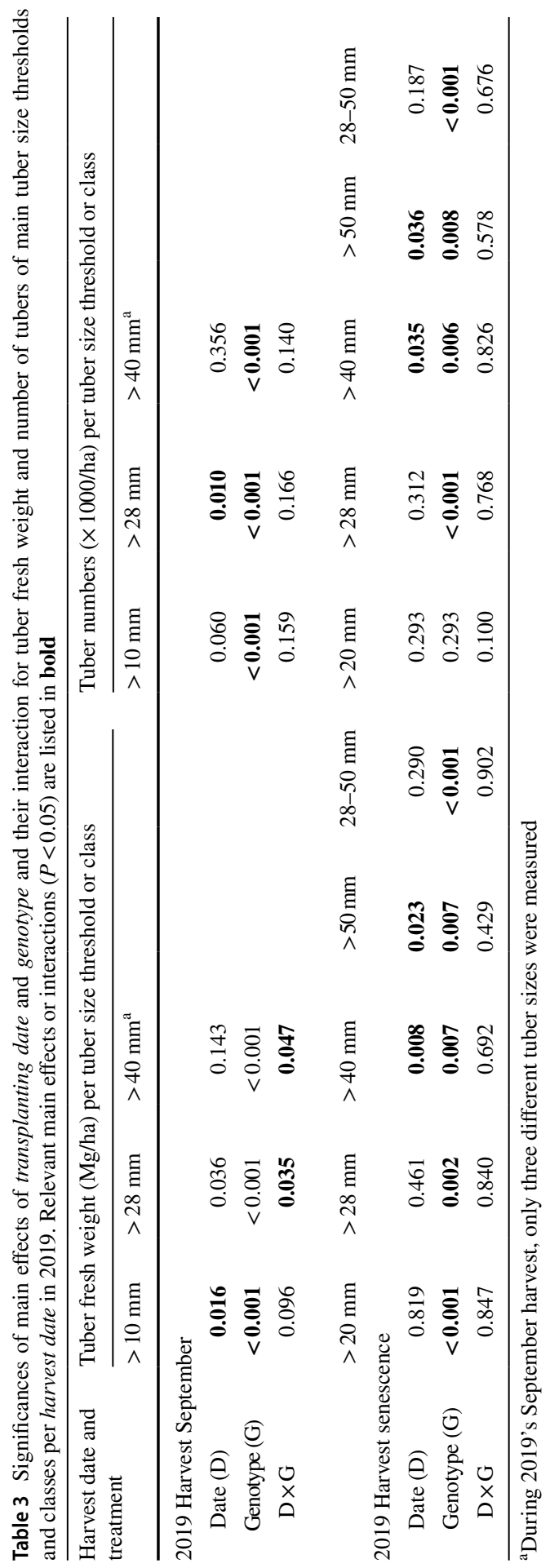




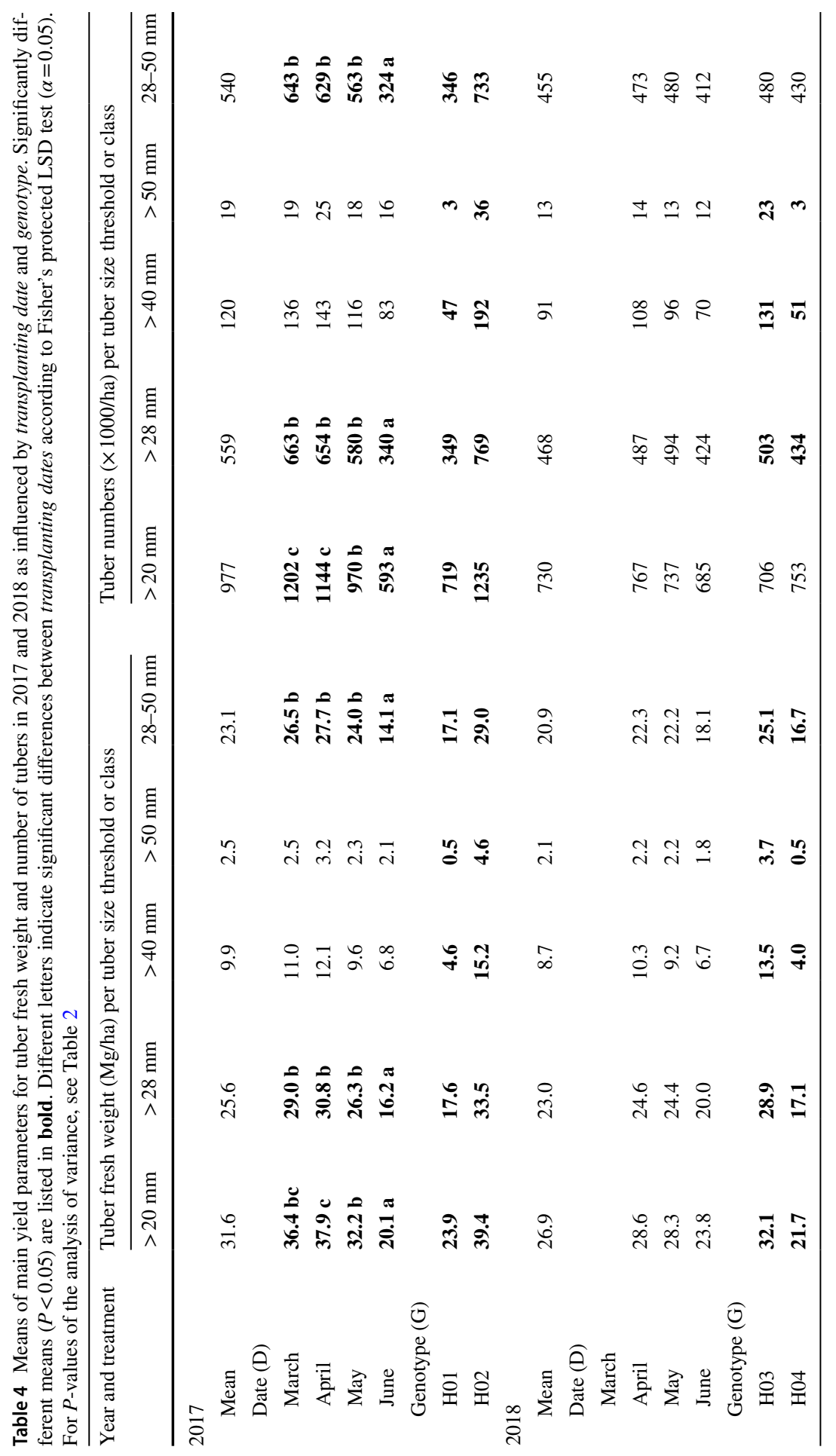


transplanting date June produced significantly lower marketable yield, $16 \mathrm{Mg} / \mathrm{ha}$, compared with the earlier transplanting dates, producing between 26 and $31 \mathrm{Mg}$ / ha, which did not differ significantly from each other (Fig. 3a-b, Table 4). The number of marketable tubers followed a similar pattern as yield; transplanting date June produced significantly fewer tubers compared with earlier dates (Fig. 3m-n, Table 4).

In 2018, no significant effects of transplanting date on marketable yield and number of tubers were observed, although a similar trend was visible as in 2017 (Table 2). A mean marketable yield of $23 \mathrm{Mg} / \mathrm{ha}$ was obtained across the transplanting dates April, May and June (Table 4, Fig. 3c-d).

In 2019, during the September harvest, interaction between the factors transplanting date and genotype was significant for marketable yield (Table 3). Highest marketable yields were obtained in genotype H07 transplanted in May or June, 40 and $37 \mathrm{Mg} / \mathrm{ha}$, respectively (Fig. 3f, Table 5). The April planting of HO7 produced a yield of $33 \mathrm{Mg} / \mathrm{ha}$, which was similar to the range of yields for genotype HO3, the second highest yielding genotype, in all three planting dates $(32-35 \mathrm{Mg} / \mathrm{ha}, \mathrm{Fig}$. 3e, Table 5). Marketable yields of genotypes HOS and HO9 were more affected by late transplanting than other genotypes (Table 5, Fig. 3g-h). A significant decrease in marketable yield of $\mathrm{H} 09$ was observed with every subsequent transplanting date, from $28 \mathrm{Mg} /$ ha when transplanted in April to only $16 \mathrm{Mg} / \mathrm{ha}$ when transplanted in June (Fig. 3h). The number of tubers harvested in September 2019 significantly differed among the transplanting dates: the earlier the transplanting was carried out, the more tubers were harvested (Table 5, Fig. 3q-t).

Seed Tubers (28-50 $\mathbf{m m}$ ) The seed tuber size class was analysed for the years 2017 and 2018. Significant transplanting date effects were observed for seed tuber yield and number of seed tubers in 2017 only (Table 2). In 2017, the highest seed tuber yield and highest number of tubers were produced when the crop was transplanted between March and May, within which seed tuber yields ranged between 24 and $28 \mathrm{Mg} / \mathrm{ha}$. The June transplanting date produced, significantly, the lowest seed tuber yield (14 Mg/ha) and the lowest number of seed tubers compared with the other transplanting dates (Table 4). In 2018, the mean seed tuber yield across transplanting dates was $21 \mathrm{Mg} / \mathrm{ha}$ (Table 4).

Total Tubers Highest total tuber yield in 2017 was attained by the transplanting dates of March and April, which produced 36 and $38 \mathrm{Mg} /$ ha, respectively (Fig. 3ab). At $32 \mathrm{Mg} / \mathrm{ha}$, the May transplanting date produced, compared with April, significantly lower yield. However, May's total tuber yield did not significantly differ from that obtained for March, but was significantly higher than that of June $(20 \mathrm{Mg} /$ ha, Table 4, Fig. 3a-b). Total number of tubers produced by the planting dates in 2017 showed a clear trend: significantly more tubers were produced in March and April, May produced significantly fewer tubers compared with the earlier transplanting dates and June produced the lowest number of tubers (Fig. 3m-n, Table 4).

In 2018, no significant effects of transplanting date were found on total yield or number of tubers (Table 2). 
Table 5 Means of main yield parameters in 2019 at both harvests influenced by transplanting date and genotype. Bold means significantly differ $(P<0.05)$. Significant differences between transplanting dates, genotypes and $D \times G$ interaction are shown with different letters, using Fisher's protected LSD test $(\alpha=0.05)$

\begin{tabular}{|c|c|c|c|c|c|c|c|c|c|c|}
\hline & \multicolumn{5}{|c|}{ Tuber fresh weight $(\mathrm{Mg} / \mathrm{ha})$ per tuber size ${ }^{\mathrm{a}}$} & \multicolumn{5}{|c|}{ Tuber numbers $(\times 1000 /$ ha $)$ per tuber size ${ }^{a}$} \\
\hline & Total $^{\mathrm{b}}$ & $>28$ & $>40$ & $>50$ & $28-50$ & Total $^{\mathrm{b}}$ & $>28$ & $>40$ & $>50$ & $28-50$ \\
\hline \multicolumn{11}{|c|}{2019 Harvest September } \\
\hline Mean & 32.9 & 26.8 & 10.2 & & & 1149 & 523 & 110 & & \\
\hline \multicolumn{11}{|l|}{ Date (D) } \\
\hline April & $35.9 \mathrm{~b}$ & $28.1 \mathrm{~b}$ & 8.2 & & & 1327 & $645 \mathrm{c}$ & 150 & & \\
\hline May & $33.5 \mathrm{~b}$ & $28.1 \mathrm{~b}$ & 11.3 & & & 849 & 513 b & 135 & & \\
\hline June & 29.4 a & 24.1 a & 10.9 & & & 895 & 481 a & 155 & & \\
\hline \multicolumn{11}{|c|}{ Genotype (G) } \\
\hline $\mathrm{H} 03$ & $37.4 \mathrm{~B}$ & $32.6 \mathrm{C}$ & $14.9 \mathrm{C}$ & & & 1024 B & 546 B & 147 B & & \\
\hline H07 & $45.2 \mathrm{C}$ & $36.4 \mathrm{D}$ & $14.2 \mathrm{C}$ & & & $1717 \mathrm{C}$ & $768 \mathrm{C}$ & 158 B & & \\
\hline H08 & 23.1 A & $16.2 \mathrm{~A}$ & $3.5 \mathrm{~A}$ & & & $1110 \mathrm{~B}$ & 395 A & 55 A & & \\
\hline H09 & $26.0 \mathrm{~A}$ & 21.9 B & 8.0 B & & & 747 A & $383 \mathrm{~A}$ & 83 A & & \\
\hline \multicolumn{11}{|l|}{$\mathrm{D} \times \mathrm{G}$} \\
\hline \multicolumn{11}{|l|}{ H03 } \\
\hline April & 40.7 & $34.5 \mathrm{e}$ & 14.0 def & & & 1327 & 645 & 150 & & \\
\hline May & 35.8 & $31.8 \mathrm{de}$ & 14.0 ef & & & 849 & 513 & 135 & & \\
\hline June & 35.8 & 31.5 de & $16.6 \mathrm{f}$ & & & 895 & 481 & 155 & & \\
\hline \multicolumn{11}{|l|}{ H07 } \\
\hline April & 44.2 & 33.0 de & $7.6 \mathrm{bc}$ & & & 2117 & 867 & 100 & & \\
\hline May & 49.1 & $39.8 \mathrm{f}$ & $15.8 \mathrm{f}$ & & & 1729 & 797 & 163 & & \\
\hline June & 42.3 & 36.5 ef & $19.3 \mathrm{f}$ & & & 1305 & 641 & 209 & & \\
\hline \multicolumn{11}{|l|}{ H08 } \\
\hline April & 23.8 & 16.9 abc & $3.0 \mathrm{ab}$ & & & 1118 & 432 & 39 & & \\
\hline May & 25.5 & 18.9 bc & 5.9 abc & & & 1055 & 412 & 68 & & \\
\hline June & 19.8 & $12.7 \mathrm{a}$ & $1.5 \mathrm{a}$ & & & 1156 & 342 & 57 & & \\
\hline \multicolumn{11}{|l|}{ H09 } \\
\hline April & 34.8 & $28.1 \mathrm{~d}$ & $8.3 \mathrm{bcd}$ & & & 988 & 508 & 80 & & \\
\hline May & 23.7 & $22.0 \mathrm{c}$ & 9.7 cde & & & 615 & 358 & 105 & & \\
\hline June & 19.5 & 15.6 ab & 6.1 abc & & & 638 & 283 & 64 & & \\
\hline \multicolumn{11}{|c|}{2019 Harvest senescence } \\
\hline Mean & 37.4 & 33.3 & 17.1 & 5.6 & 27.7 & 813 & 532 & 153 & 31 & 501 \\
\hline \multicolumn{11}{|l|}{ Date (D) } \\
\hline April & 36.7 & 31.5 & $13.5 \mathrm{a}$ & $3.1 \mathrm{a}$ & 28.5 & 913 & 563 & 132 a & 19 a & 544 \\
\hline May & 38.5 & 34.4 & $17.3 \mathrm{~b}$ & $5.3 \mathrm{a}$ & 29.1 & 832 & 549 & $156 \mathrm{~b}$ & 29 a & 520 \\
\hline June & 37.0 & 34.0 & $20.4 \mathrm{c}$ & $8.3 \mathrm{~b}$ & 25.6 & 695 & 485 & $172 \mathrm{~b}$ & $45 \mathrm{~b}$ & 440 \\
\hline \multicolumn{11}{|c|}{ Genotype (G) } \\
\hline $\mathrm{H} 03$ & 37.9 B & $35.2 \mathrm{~B}$ & $22.3 \mathrm{~B}$ & $9.8 \mathrm{C}$ & 25.4 A & $685 \mathrm{AB}$ & $489 \mathrm{~A}$ & $185 \mathrm{BC}$ & $52 \mathrm{C}$ & $437 A$ \\
\hline H07 & $53.1 \mathrm{C}$ & 46.7 C & $22.8 \mathrm{~B}$ & $7.3 \mathrm{BC}$ & $39.4 \mathrm{~B}$ & $1249 \mathrm{C}$ & 804 B & $217 \mathrm{C}$ & $43 \mathrm{BC}$ & $761 \mathrm{~B}$ \\
\hline H08 & $28.2 \mathrm{~A}$ & $23.5 \mathrm{~A}$ & $8.1 \mathrm{~A}$ & $1.2 \mathrm{~A}$ & $22.3 \mathrm{~A}$ & 758 B & $441 A$ & $81 \mathrm{~A}$ & $8 \mathrm{~A}$ & $433 A$ \\
\hline H09 & $30.3 \mathrm{AB}$ & $27.8 \mathrm{AB}$ & 15.1 AB & $3.9 \mathrm{AB}$ & 23.8 A & $560 \mathrm{~A}$ & $395 \mathrm{~A}$ & $131 \mathrm{AB}$ & $22 \mathrm{AB}$ & 373 A \\
\hline
\end{tabular}

${ }^{\mathrm{a}}$ size threshold or class in $\mathrm{mm}$;

${ }^{\mathrm{b}}$ Total $>10 \mathrm{~mm}$ for September, $>20 \mathrm{~mm}$ for senescence 
During the September harvest in 2019, the April and May transplanting dates produced significantly higher total yields of 36 and $34 \mathrm{Mg} /$ ha, respectively. June followed with $29 \mathrm{Mg} / \mathrm{ha}$, see Table 5 .

Large Tubers No significant effects of transplanting date were observed in the larger tuber size classes with thresholds of $>40 \mathrm{~mm}$ and $>50 \mathrm{~mm}$ in 2017 and 2018 (Table 2). However, in 2019, a date $\times$ genotype interaction was significant for yield at the tuber size threshold $>40 \mathrm{~mm}$ (Tables 3 and 5). Significantly higher yields of tubers $>40 \mathrm{~mm}$ were harvested for the May and June transplanting date for $\mathrm{HO}$ than for its April date (Fig. 3f). The tuber yields $>40 \mathrm{~mm}$ of $\mathrm{HO3}$ ranged between 14 and $19 \mathrm{Mg} / \mathrm{ha}$ (Fig. 3e) but were not significantly different between the transplanting dates. Compared with $\mathrm{HO}$ and H07, genotypes $\mathrm{HOS}$ and $\mathrm{HO}$ produced significantly lower tuber yield $>40 \mathrm{~mm}$, without any significant effects of transplanting date within the genotypes H08 or H09 (Fig. 3g-h, Table 5).

\section{Genotypic Differences in Yield and Number of Tubers on a Conventional Harvest Date}

In 2017, the genotypes showed significant differences in yield and number of tubers, as shown in Table 2. For all parameters, genotype HO2 produced a higher yield and more tubers than $\mathrm{HOl}$ (Table 4, Fig. 3a-b, m-n). Marketable yield of HO2 was $34 \mathrm{Mg} / \mathrm{ha}$, almost twice as much as the $18 \mathrm{Mg} / \mathrm{ha}$ produced by $\mathrm{HOl}$ (Fig. 3a-b). H02's seed tuber yield was $29 \mathrm{Mg} / \mathrm{ha}$ compared with $17 \mathrm{Mg} / \mathrm{ha}$ produced by $\mathrm{HOl}$ (Table 4).

In 2018, genotypes significantly differed for all parameters except for number of tubers $>20 \mathrm{~mm}$ and number of seed tubers (Table 2). For all significantly different variables, genotype HO3 produced more yield and more tubers than $\mathrm{HO4}$ (Table 4, Fig. $3 \mathrm{c}-\mathrm{d}, \mathrm{o}-\mathrm{p}$ ). HO3 produced 29 and $25 \mathrm{Mg} / \mathrm{ha}$ for marketable and seed tuber yield, respectively, compared with $17 \mathrm{Mg} / \mathrm{ha}$ for $\mathrm{HO4}$ marketable and seed tuber yield (Table 4, Fig. 3c-d).

During the September harvest in 2019, significant differences between genotypes were observed for number of marketable tubers, total tuber yield and total number of tubers as well as for number of tubers $>40 \mathrm{~mm}$ (Tables 3 and 5). The highest total tuber yield, $45 \mathrm{Mg} / \mathrm{ha}$, was produced by genotype $\mathrm{HO7}$, followed by $\mathrm{HO} 3$ which produced $37 \mathrm{Mg} / \mathrm{ha}$. Genotypes HO8 and H09 produced the lowest total tuber yield, 23 and $26 \mathrm{Mg} / \mathrm{ha}$, respectively (Fig. 3e-h, Table 5).

\section{Transplanting Date and Genotypic Effects on Yield and Number of Tubers During a Prolonged Cropping Cycle}

In contrast to the 2019 September harvest, which was before crop senescence, the fully senesced crop showed no significant effects of transplanting date or date $\times$ genotype interactions for the marketable and total tuber yield and numbers of tubers. The seed tuber size class yield and number of tubers were also not affected by transplanting date (Table 3). Measured mean yields were 33, 28 and $37 \mathrm{Mg} / \mathrm{ha}$ 
for marketable, seed tuber and total yields, respectively (Table 5). The yield and number of larger-sized tubers, $>40$ and $>50 \mathrm{~mm}$, significantly differed among transplanting dates (Table 3 ). The yield of tubers $>40 \mathrm{~mm}$ increased significantly with every subsequent transplanting date (Table 5). Transplanting in April, May and June produced 14, 17 and $20 \mathrm{Mg} /$ ha tuber yield $>40 \mathrm{~mm}$, respectively. Yield of tubers $>50 \mathrm{~mm}$ was significantly higher when transplanted in June $(8 \mathrm{Mg} / \mathrm{ha}$, Table 5, Fig. 3i-1) than when transplanted in April or May (3-5 Mg/ha).

Significant genotype effects were observed for all measured variables at the senescence harvest (Table 3). Similar to 2019's September harvest, H07 produced, significantly, the highest marketable and total tuber yields (47 and $53 \mathrm{Mg} / \mathrm{ha}$, respectively; Table 5, Fig. 3j). The second highest marketable and total tuber yields were produced by $H 03$, which produced 35 and $38 \mathrm{Mg} /$ ha, respectively (Fig. 3i). HOS and H09 produced significantly lower marketable yield and total tuber yield compared with the other two genotypes (Table 5). The highest seed tuber yield was produced by $H 07,39 \mathrm{Mg} / \mathrm{ha}$ (Table 5). Significantly lower seed tuber yields were produced by $\mathrm{HO3,HOS}$ and $H 09$, with yields between 22 and $25 \mathrm{Mg} / \mathrm{ha}$, which did not significantly differ from each other (Table 5).

\section{Discussion}

The aim of this study was to assess and understand - under Dutch field conditions - the effects of the date of transplanting of greenhouse-raised hybrid potato seedlings and the age of seedlings at transplanting on potato yield. The possibilities of growing a full potato crop from transplanted hybrid seedlings and possible options for producing optimum yields while reducing the risk of unfavourable conditions will be discussed.

Over 3 years of experiments, all transplanting dates were able to produce reasonable yields, whereas highest measured marketable yields over transplanting dates ranged between 29 and $34 \mathrm{Mg} /$ ha (Tables 4, 5). Highest seed tuber yields attained were between 26 and $29 \mathrm{Mg} / \mathrm{ha}$. The current study shows that earlier transplanting, in March and April, does not obviously result in higher marketable or seed tuber yields. The earliest studied date, March, was highly prone to risks of crop failure due to low temperatures and (night) frost. Under Dutch circumstances, night frost risks and incidental colder temperatures are present until mid-May. However, the effect of transplanting date was much smaller and less pronounced than anticipated, rather, the use of different experimental hybrid genotypes determined the differences in yield levels, which partly might have been caused by their differences in crop cycle length.

\section{Effects of Seedling Age at Transplanting}

In 2017 and 2018, field transplanting of 4- and 6-week-old seedlings showed no significant effects of seedling age on yield and number of tubers (Table 2). Due to the lack of significant influence of the seedling ages on yield parameters over the first 
two trial seasons, an optimal age for field transplanting could not be determined in this study. Therefore, and due to adequate performance of 5-week-old seedlings in recent studies (Kacheyo et al. 2021; van Dijk et al. 2021), only 5-week-old seedlings were used in 2019.

Seedling age at transplanting is entangled with the seedling development and phenology at transplanting. The use of transplant age to characterise transplantable seedlings was largely based on the time taken from sowing, through hardening off, up until transplanting. To assure a uniform selection of transplantable seedlings and eliminate off-types, an additional selection based on seedling growth stage, vigour and size was carried out. This resulted in seedlings with a stem of $2-3 \mathrm{~cm}$ and $2-4$ true leaves, seedlings with a stem of 7-12 $\mathrm{cm}$ and 5-8 leaves and seedlings with a stem $>14 \mathrm{~cm}$ and $>8$ true leaves (see 'Materials and Methods') being selected for the different age classes (4, 5 and 6 weeks) under the experimental conditions. However, seed quality, precision of sowing and conditions during germination $(\mathrm{BBCH}$ stage 01-05, Kacheyo et al. 2021) and emergence (BBCH stage 07-09, Kacheyo et al. 2021) (Almekinders 1995; Lamichhane et al. 2018) among other factors do influence the growth of seedlings in a nursery (Buishand et al. 1985; Everaarts et al. 1993; Kerbiriou et al. 2013). At the moment, the conditions for optimal growth of hybrid seedlings in the greenhouse nursery as well as the optimal period and conditions of the seedling hardening-off phase have not been studied in detail, nor defined.

\section{Night Frost Impacted the Effects of Transplanting Date}

The choice of the time to transplant (Table 1) was guided by possible adverse effects of the environmental conditions, especially in the initial stages of crop growth. Fig. 4 shows details on the minimum temperatures and frost sums around the different planting dates in the three experimental years. Field establishment of seedlings from the earliest date, March, was only achieved in 2017, when only sparse occurrences of frost were observed in March (Fig. 4a) and the mild frost conditions allowed the transplants to establish and withstand the frosts. In 2018, the March planted seedlings were heavily affected by frost (Fig. 4b) despite the covering with a plastic film during the period when temperatures were $<2{ }^{\circ} \mathrm{C}$. Plants did not manage to survive the stresses induced by the frost, leading to the loss of all plants of this transplanting date. The different effects of frost in the 2 years might be attributed to a combination of incidence of frost at the date of transplanting and a frost sum (frost- $\Sigma$ ) of $-20{ }^{\circ} \mathrm{Cd}$ within the first 1.5 week in the field in 2018 (Fig. 4b). Additionally, in 2017, the April date also coincided with frost occurrences, although not on the day of transplanting and also less violent than in 2018's March date (Fig. 4a). In April 2019, frost occurred the second night after transplanting, and a frost- $\Sigma$ of $-6.6{ }^{\circ} \mathrm{Cd}$ was reached on the fifth day in the field (Fig. 4c). Plants were visibly affected by frost, but recovered in the following weeks. Therefore, transplanting in March, but also early in April, is precarious as any prolonged occurrence of frost may result in accumulated effects which may eventually cause irreversible damage 


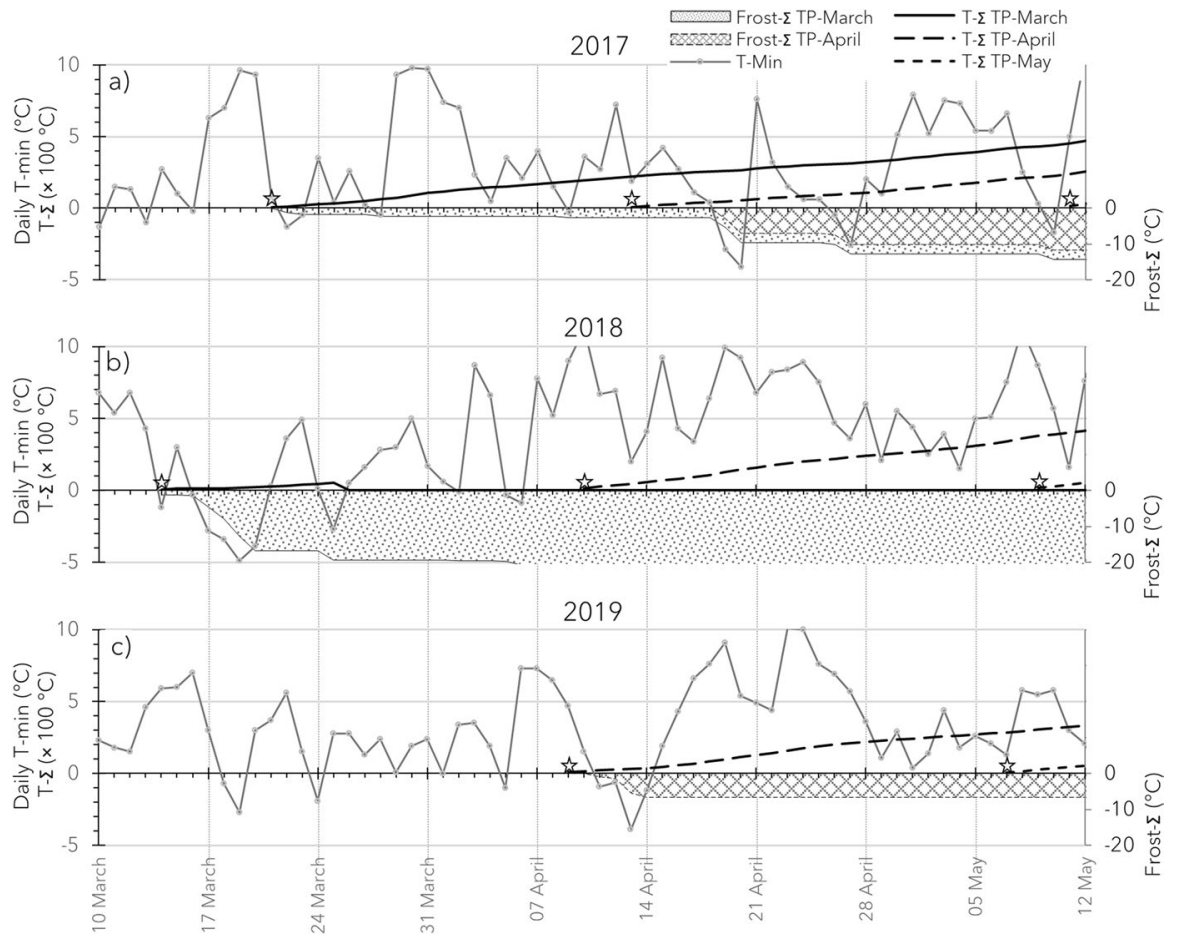

Fig. 4 Detailed zoom-in on the colder (between -5 and $10^{\circ} \mathrm{C}$ ) daily minimum temperatures (T-min), the temperature sum $(\mathrm{T}-\Sigma)$ per transplanting (TP) date and the sum of negative temperatures (frost- $\Sigma$ ) per transplanting date for the periods from 10 March until the latest night frost event (10 May) in the three experimental years (for all $\Sigma \mathrm{T}$-base $=0{ }^{\circ} \mathrm{C}$ ). Dates of transplanting are indicated with stars

to the plants. In addition, under Dutch conditions, the local field situation might be too wet to prepare a decent planting bed or ridges in early spring (Poll et al. 1994).

\section{Contribution of Transplanting Date to Tuber Yield on a Conventional Harvest Date}

The duration of a crop's growing period strongly influences crop yield. For a potato crop, temperature and radiation are important yield-determining factors when grown under non-limiting conditions. Furthermore, the crop cycle length of a cultivar may also influence the yield attained at the time of harvest, with long cycle cultivars requiring a longer growing period (Kooman 1995).

Transplanting in March as well as April advanced the crop growth cycle from transplanting up to the conventional September harvest, but coincided with the risk of frost. When comparing the abovementioned advanced crop growth cycles - starting in March or April - with starting in May, the additional accumulated PAR and temperature (Fig. 1) did not result in more yield (Tables 4 and 5). Thus, on average, the crop formed less tuber FW per day in the field when transplanted early than when transplanted in May. When transplanted in June, on the other hand, 
accumulation of tuber FW per day was high, but when harvested in September, the crop cycle duration was too short to make similar yields as the other transplanting dates. Therefore, prospects for field transplanting exercises for a successful growing period in the conventional cropping cycle - September harvest - gravitate towards transplanting on the April or May dates. Hence, this study defines the optimal window for field transplanting of hybrid potato seedlings between the beginning of April and the end of May. A defined optimal transplanting date is an important ingredient to add to the novel method for production of seed(ling) tubers for the current Dutch potato sector.

\section{Contribution of Crop Cycle Length to Experimental Hybrid Genotypes Tuber Yield}

Fig. 5 shows a general trend (not significantly tested) where a shorter crop cycle results in lower marketable yields. However, the figure also shows that the individual experimental genotypes used in this study differ in the number of days needed to reach their maximum yield.

For instance, interpolation between planting dates of $H 01$ in 2017 shows that maximum marketable yield was attained at around 130 DAT, compared with 160 DAT for HO2, which reflects transplanting in May and April, respectively, when harvested in September (Fig. 5a). Also in 2018 (Fig. 5b), the effects of additional days in the crop cycle on the marketable yield in September seemed to be largely genotype dependent; genotype $\mathrm{HO4}$ reached its maximum yield already at about 100 DAT (transplanting in June) - a longer growing period did not result in additional yield - and genotype HO3 needed at least 130 days in the field (May date) to reach maximum yield.

In 2019, when four genotypes were used and two harvests were conducted - in September and at crop senescence - differences in yield and number of marketable tubers among genotypes were clearly observed (Fig. 3e-1, Table 5). Additionally, the effect of a prolonged crop cycle was observed per genotype for each transplanting date (Fig. 5c-f). The amount of additional marketable yield from the early (September) to the late (senescence) harvest differed much among genotypes, increasing the length of the crop cycle showed most effect for the late planting in June.

Based on Fig. 5, transplanting in June and harvesting in September seems more feasible for a short cycle cultivar. Transplanting dates April and May would be more suitable for medium cycle cultivars when harvested in September and long crop cycle cultivars when harvested in October at crop senescence. The choices of the date of transplanting and the date of harvest are strongly influenced by the duration of the genotype's crop cycle, the suitability of the genotype for a given set of environmental conditions and purpose.

\section{Opportunities for Potato Cropping Systems Under Dutch Conditions}

Fig. 5 indicates that the effects of crop cycle length on yield were genotype dependent. As Fig. 5 also suggests that both manipulation of the crop cycle duration at the 

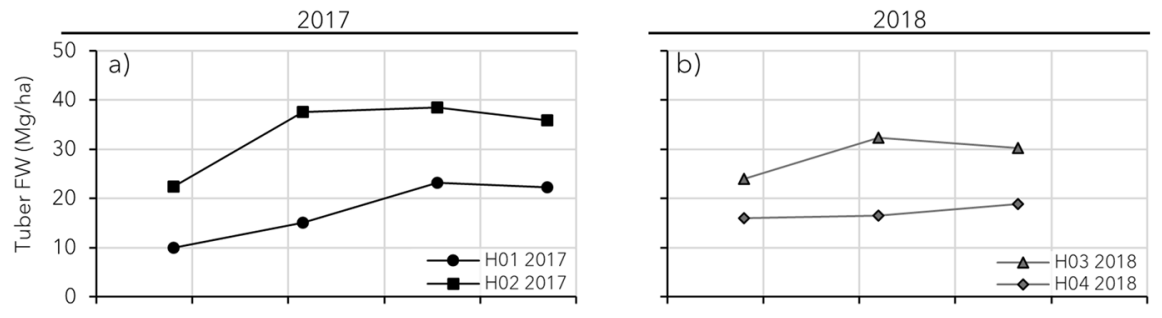

2019
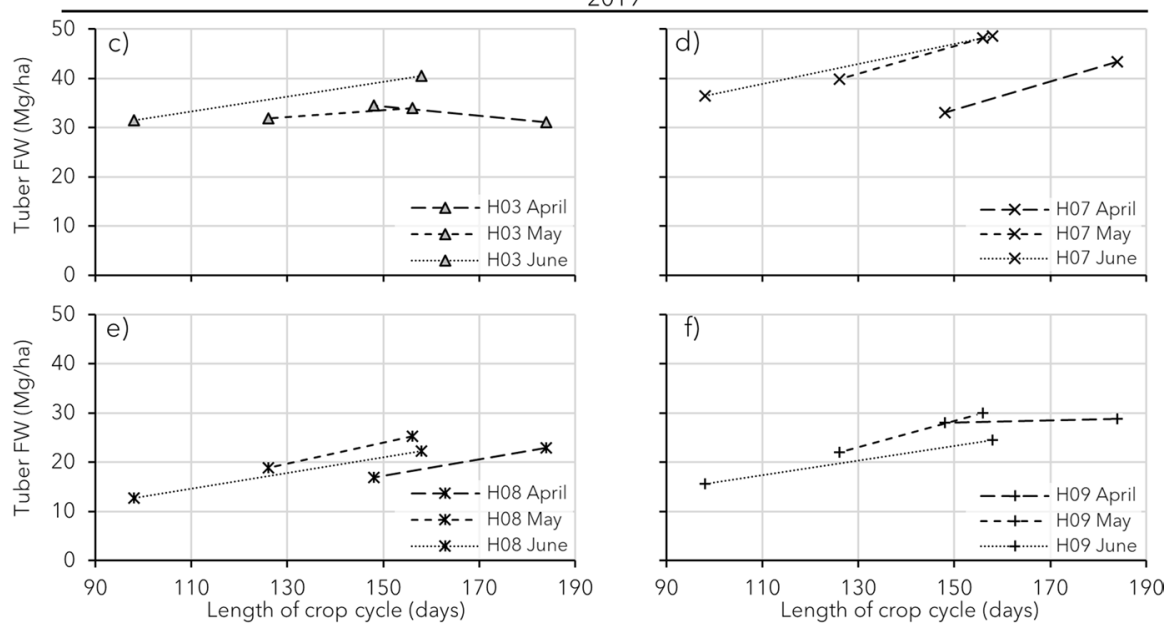

Fig. 5 Produced marketable yield $(>28 \mathrm{~mm}$ ) plotted against the length of the growing period in the field. As in 2017 (a) and 2018 (b), the harvest of all transplanting dates was carried out on the same day in September, the shortest growing period was created by transplanting date in June, of which marketable yield is indicated with the most left marker. Panels $\mathbf{c}, \mathbf{d}$, e and $\mathbf{f}$ correspond with the 2019 transplanted genotypes $\mathrm{HO3,H07,HOS} \mathrm{and} \mathrm{H09,} \mathrm{respectively.} \mathrm{Per} \mathrm{transplanting} \mathrm{date,} \mathrm{the} \mathrm{left-side} \mathrm{marker} \mathrm{corresponds}$ with the harvest in September and the right-side marker with the harvest at crop senescence

start (planting) or at the end (harvest) could have considerable effects on the yield of some of the experimental hybrid genotypes used in this study. Besides, in more general, this study showed that early or late transplantings (March or June, respectively) were disadvantageous for the used experimental genotypes. Yet, combined with the innovation of hybrid potato breeding, early or late transplanting of hybrid diploid genotypes may give - hypothetically — a whole new set of opportunities to Dutch arable farmers.

The genotypes in this study could withstand short periods of colder and frosty conditions, as shown in Fig. 4. Because hybrid potato breeding at the diploid level gives breeders the possibilities for more targeted introduction or stacking of favourable genes (Su et al. 2020), possibilities arise for breeding both short and long crop cycle genotypes as well as cold or frost tolerant genotypes (Bethke et al. 2019). Short cycle hybrid genotypes will allow growers to cultivate and harvest a potato crop in a shorter crop cycle compared with intermediate or long crop cycle genotypes. It allows growers to cultivate besides (hybrid) potatoes also specific green manure and/or catch crops which are meant to increase soil organic matter, 'catch' 
the surplus of soil nitrogen and release it in the next season or reduce the number of plant parasitic nematodes by interrupting their life cycle. Growing such crops in the same growing season as a potato main crop fits perfectly in the new ambitions of the Dutch government and agricultural sector to strive for a more circular and agricultural system, depending less on external (chemical) inputs.

Moreover, short cycle hybrid potato will be an ideal new crop for vegetable growers in the Netherlands. Due to their experience with transplanted vegetable crops like cabbage, lettuce, spinach, leek, broccoli, endive and celery, integration of hybrid transplanted potato into their existing systems may be effortless. The aforementioned vegetables either have short cropping cycles and/or cold tolerance, which allows for early planting; or are hardy, thereby allowing for a late planting and later harvest during winter periods.

The machinery used in these vegetable cropping systems can also be used in transplanting and management of hybrid potato seedling crops. Furthermore, most agronomic practices such as cultivation practices, irrigation practices and management of frost by covering with plastic films can be adapted for new transplanted hybrid potato systems.

Additionally, short crop cycle varieties which tolerate late season transplanting including long haulm-stay-green traits will allow growers to include a potato cultivation - together with short-season vegetables - at the end of the cropping season. Ideally, these new hybrid potato varieties have the potential to serve the fresh potato market, focusing on consumer traits like taste, nutrition value and quality. Cultivation directly from hybrid TPS will allow growers to quickly anticipate for new hybrid varieties with improved resistances or changed preferences in the consumer markets compared with a traditionally bred crop grown from seed tubers.

\section{Further Studies}

The current study did not present a clear answer on the most suitable transplanting dates — March to June - for yield and number of tubers. As significant effects of genotype and interactions of genotype and the transplanting date were present in every season, it is critical to determine the optimal date of transplanting hybrid potato seedlings. It is suggested to study this in a set of experiments solidly replicated in space and time. Especially, when considering the next step of innovation in hybrid potato breeding where the shift will be made from experimental hybrid genotypes to hybrid varieties for specific potato production markets. When new hybrid potato cultivars with distinct crop cycle types will be available, it is recommended to do more detailed studies on the feasible window of transplanting to produce optimum yields. As all transplanting dates in this study occurred in the first half of the month, it is also important to identify the optimal date of transplanting within the months of April and May. 
In addition, more insight is needed into the ideal size of a seedling for transplanting. These studies should also take into account the nursery conditions needed to produce seedlings of a desired size and additional hardening-off and field management practices which also contribute to a minimal transplanting shock.

\section{Conclusions}

The choice of transplanting date greatly influences transplant establishment and yield because very early planting in March comes with increased risks of crop failure due to extended frost. However, hybrid potato breeding might anticipate on decreasing these risks in the future. No clear differences between transplanting dates have been observed for April, May and June dates when harvested at complete senescence. However, at the conventional harvest time in September, transplanting dates April and May were able to out-yield June. For larger tuber sizes (>40 mm), harvesting at earlier crop stages other than complete senescence showed interactions between transplanting date and the genotype whereas at complete senescence, a significant transplanting date effect was observed; late planting in June seemed to increase the share of larger-sized tubers and enhance yields.

The yields of 4- and 6-week-old seedlings were not significantly different. However, it is currently not known if 5-week-old seedlings might outperform the former due to a more ideal size or stage of development.

Genotypic effects were substantial in all seasons, and for some genotypes, the length of the cropping cycle might be more important than the date of transplanting. Harvesting in September, when transplanted in June, seemed to be too early to deliver a fully matured crop using its full yield potential. The choice of time to harvest especially for late planting dates is therefore influenced by the time of transplanting and the crop cycle length of the genotype.

Low minimum temperatures in early May did not seem to have much effect on the crops as they did not result in crop failure or lower yields compared with transplanting in June. Moreover, the experimental genotypes could withstand periods of low maximum day temperatures and several short events of night frost, which hints to a certain degree of cold tolerance in the diploid hybrid genotypes used. Introducing traits favouring short cropping cycles and cold/frost tolerance with hybrid breeding does create the opportunity to grow potato as a transplantable vegetable under Dutch agronomical conditions.

Supplementary Information The online version contains supplementary material available at https://doi. org/10.1007/s11540-021-09524-x.

Author Contribution LCMvD designed the experiments. LCMvD and OCK managed the field trials and collected the data. LCMvD analysed the data. Data interpretation and drafting the manuscript were done by LCMvD and OCK. The manuscript was revised based on input of all authors. All authors approved the final version. 
Funding This study was part of the Potarei project funded by the Responsible Research and Innovation programme of the Netherlands Organisation for Scientific Research (NWO; 313-99-301). Additional funding came from Solynta, Kramp Group and Ubbo Emmius Fund.

Availability of Data and Material Yes.

Code Availability Not applicable.

\section{Declarations}

Ethics Approval Not applicable.

Consent to Participate Not applicable.

Consent for Publication Yes.

Conflict of Interest WJML is editor of Potato Research; PCS is editor-in-chief of Potato Research.

Open Access This article is licensed under a Creative Commons Attribution 4.0 International License, which permits use, sharing, adaptation, distribution and reproduction in any medium or format, as long as you give appropriate credit to the original author(s) and the source, provide a link to the Creative Commons licence, and indicate if changes were made. The images or other third party material in this article are included in the article's Creative Commons licence, unless indicated otherwise in a credit line to the material. If material is not included in the article's Creative Commons licence and your intended use is not permitted by statutory regulation or exceeds the permitted use, you will need to obtain permission directly from the copyright holder. To view a copy of this licence, visit http://creativecommons.org/licen ses/by/4.0/.

\section{References}

Almekinders CJM (1995) On flowering and botanical seed production in potato (Solanum tuberosum L.). Dissertation, Wageningen University

Almekinders CJM, Chilver AS, Renia HM (1996) Current status of the TPS technology in the world. Potato Res 39(2):289-303. https://doi.org/10.1007/BF02360921

Almekinders CJM, Chujoy E, Thiele G (2009) The use of true potato seed as pro-poor technology: the efforts of an international agricultural research institute to innovating potato production. Potato Res 52(4):275-293. https://doi.org/10.1007/s11540-009-9142-5

Bethke PC, Halterman DA, Jansky SH (2019) Potato germplasm enhancement enters the genomics era. Agronomy 9(10):575-575. https://doi.org/10.3390/agronomy9100575

Buishand T, Snoek NJ, Titulaer HHH, Bosch HKJ, de Jonge PAF (1985) Teelt van sluitkool; Teelthandleiding nr. 17. PAGV, Lelystad. https://edepot.wur.nl/252304

van Dijk LCM, Lommen WJM, de Vries ME, Kacheyo OC, Struik PC (2021) Hilling of transplanted seedlings from novel hybrid true potato seeds does not enhance tuber yield but can affect tuber size distribution. Potato Res. 64:353-374. https://doi.org/10.1007/s11540-020-09481-x

Everaarts AP, Zwanepol S, Alblas J, Hylkema HJ (1993) Teelt van broccoli; Teelthandleiding nr. 54. PAGV, Lelystad. http://edepot.wur.nl/252740

Ewing EE, Struik PC (1992) Tuber formation in potato: induction, initiation, and growth. In: Janick J (ed) Horticultural Reviews, vol 14. Wiley, New York, pp 89-198. https://doi.org/10.1002/9780470650523.ch3

Hijmans RJ, Condori B, Carillo R, Kropff MJ (2003) A quantitative and constraint-specific method to assess the potential impact of new agricultural technology: the ease of frost resistant potato for the Altiplano (Peru and Bolivia). Agr Syst 76(3):895-911. https://doi.org/10.1016/S0308-521X(02)00081-1 
Jansky SH, Charkowski AO, Douches DS, Gusmini G, Richael C, Bethke PC, Spooner DM, Novy RG, De Jong H, De Jong WS, Bamberg JB, Thompson AL, Bizimungu B, Holm DG, Brown CR, Haynes KG, Sathuvalli VR, Veilleux RE, Miller C, Bradeen JM, Jiang J (2016) Reinventing potato as a diploid inbred line based crop. Crop Sci 56(4):1412-1422. https://doi.org/10.2135/cropsci2015.12.0740

Kacheyo OC, van Dijk LCM, de Vries ME, Struik PC (2021) Augmented descriptions of growth and development stages of potato (Solanum tuberosum L.) grown from different types of planting material. Ann Appl Biol 178(3):549-566. https://doi.org/10.1111/aab.12661

Kerbiriou PJ, Stomph TJ, Lammerts van Bueren ET, Struik PC (2013) Influence of transplant size on the aboveand below-ground performance of four contrasting field-grown lettuce cultivars. Front Plant Sci 4(379):116. https://doi.org/10.3389/fpls.2013.00379

Kooman PL, Fahem M, Tegera P, Haverkort AJ (1996) Effects of climate on different potato genotypes 1. Radiation interception, total and tuber dry matter production. Eur J Agron 5(3):193-205. https://doi.org/10.1016/S1161-0301(96)02031-X

Kooman PL, Fahem M, Tegera P, Haverkort AJ (1996) Effects of climate on different potato genotypes 2. Dry matter allocation and duration of the growth cycle. Eur J Agron 5(3):207-217. https://doi.org/10.1016/ S1161-0301(96)02032-1

Kooman PL (1995) Yielding ability of potato crops as influenced by temperature and daylength. Dissertation, Wageningen University

de Kraker J, Bosch H, Alblas J (1993) Teelt van prei; Teelthandleiding nr. 56. PAGV, Lelystad. https:// edepot.wur.nl/252312

Lamichhane JR, Debaeke P, Steinberg C, You MP, Barbetti MJ, Aubertot JN (2018) Abiotic and biotic factors affecting crop seed germination and seedling emergence: a conceptual framework. Plant Soil 432:1-28. https://doi.org/10.1007/s11104-018-3780-9

Lindhout P, Meijer D, Schotte T, Hutten RCB, Visser RGF, van Eck HJ (2011) Towards F1 hybrid seed potato breeding. Potato Res 54(4):301-312. https://doi.org/10.1007/s11540-011-9196-Z

Lindhout P, de Vries M, ter Maat M, Su Y, Viquez-Zamora M, van Heusden S (2018) Hybrid potato breeding for improved varieties. In: Wang-Pruski G (ed) Achieving Sustainable Cultivation of Potatoes Vol 1. Burleigh \& Dodds Science Publishing, Cambridge, pp 99-123. https://doi.org/10.19103/AS.2016.0016.04

Lommen WJM (1999) Causes for low tuber yields of transplants from in vitro potato plantlets of early cultivars after field planting. J Agric Sci 133(3):275-275. https://doi.org/10.1017/S002185969900698X

Muthoni J, Kabira J, Shimelis H, Melis R (2014) Producing potato crop from true potato seed (TPS): a comparative study. Aust J Crop Sci 8(8):1147-1151. http://www.cropj.com/muthoni_8_8_2014_1147_1151.pdf

Neuvel JJ, Zwanepol S, Titulaer HHH, Stolk JH, de Kraker J (1991) Teelt van tuinbonen; Teelthandleiding nr. 33. PAGV, Lelystad. http://edepot.wur.n1/253088

Poll JTK, Bosch H, Jonkers J, Meier R, Titulaer, HHH (1994) Teelt van andijvie; Teelthandleiding nr. 65. PAGV, Lelystad. http://edepot.wur.n1/252735

Reekie JY, Hicklenton P, Duval J, Chandler C, Struik PC (2005) Leaf removal and prohexadione-calcium can modify Camarosa strawberry nursery plant morphology for plasticulture fruit production. Can J Plant Sci 85(3):665-670. https://doi-org.ezproxy.library.wur.nl/10.4141/P04-100

Reekie JY, Struik PC, Hicklenton P, Duval J (2007) Dry matter partitioning in a nursery and a plasticulture fruit field of strawberry cultivars 'Sweet Charlie' and 'Camarosa' as affected by prohexadione-calcium and partial leaf removal. Eur J Hortic Sci 72(3):122-129. https://www.pubhort.org/ejhs/2007/file_338683.pdf

Snoek NJ, Dekkers WA, Bosch H (1985) Teelt van sla; Teelthandleiding nr. 19. PAGV, Lelystad. https:// edepot.wur.n1/252310

Stockem J, de Vries M, van Nieuwenhuizen E, Lindhout P, Struik PC (2020) Contribution and stability of yield components of diploid hybrid potato. Potato Res 63:345-366. https://doi.org/10.1007/s11540-019-09444-X

Stokstad E (2019) The new potato. Science New York 363(6427):574-577. https://doi.org/10.1126/science.363.6427.574

Su Y, Viquez-Zamora M, den Uil D, Sinnige J, Kruyt H, Vossen J, Lindhout P, van Heusden S (2020) Introgression of genes for resistance against Phytophthora infestans in diploid potato. Am J Potato Res 97:33-42. https://doi.org/10.1007/s12230-019-09741-8

Timmer RD, Jansen H, Staal J, Nijenhuis CMA, de Jonge P (1989) Teelt van droge erwten; Teelthandleiding nr. 28. PAGV, Lelystad. http://edepot.wur.nl/254841

Wiersema SG (1984) The production and utilization of seed tubers derived from true potato seed. University of Reading, Dissertation https://wur.on.worldcat.org/oclc/67707775

Publisher's Note Springer Nature remains neutral with regard to jurisdictional claims in published maps and institutional affiliations. 